\title{
PENGARUH TERAPI MEDITASI DAN YOGA TERHADAP GANGGUAN KECEMASAN PASCA BENCANA BANJIR DI DESA ALAT KECAMATAN HANTAKAN
}

\author{
Annida Hasanah ${ }^{*}$, Muji Palhadad ${ }^{2}$, Rian Tasalim ${ }^{3}$ \\ ${ }^{1,2,3}$ Fakultas Kesehatan, Universitas Sari Mulia (UNISM) Banjarmasin
}

*Email : annidahas1698@gmail.com

\begin{abstract}
ABSTRAK
Kecemasan merupakan respon alami dari individu yaitu berupa rasa takut yang tidak jelas disertai dengan perasaan ketidakamanan, ketidakpastian, isolasi dan ketidakberdayaan akibat bencana yang mengancam jiwa serta pengalaman traumatis yang berlangsung terus- menerus sehingga mengganggu kehidupan sehari- hari. Penanganan yang tepat untuk korban bencana yang mengalami kecemasan salah satunya dengan terapi meditasi dan yoga. Terapi ini coba diterapkan oleh tim pengabdi pada kelompok sasaran Pengabdian Kepada Masyarakat (PKM) ini yaitu kelompok ibu rumah tangga berjumlah 20 orang dari RT yang berbeda-beda di Desa Alat Kecamatan Hantakan, Hulu Sungai Tengah (HST), Kalimantan Selatan. Kegiatan pengabdian kepada masyarakat dilaksanakan dengan pendekatan community development, bekerjasama dengan anggota masyarakat sekitar. Terdapat 3 tahapan kegiatan PKM yaitu tahap persiapan, tahap pelaksanaan dan tahan evaluasi. Tahap persiapan dimulai dengan kerjasama antara tim pengabdi dengan kelompok masyarakat di Desa Alat Kecamatan Hantakan. Tahap Pelaksanaan dilakukan pada bulan Maret 2021, dengan melakukan pengukuran tingkat kecemasan menggunakan kuisioner SRQ-20, dilanjutkan memberikan terapi meditasi dan terapi yoga kepada 20 Orang ibu rumah tangga. Tahap evaluasi dilakukan dengan pengukuran tingkat kecemasan menggunakan kuisioner SRQ-20 setelah beberapa saat dilakukan kegiatan meditasi dan yoga. Hasil kegiatan PKM didapatkan dari 20 orang ibu rumah tangga yang menjadi sasaran PKM, terdapat 17 orang yang mengalami gangguan kecemasan. Setelah diberikan tindakan meditasi dan yoga, hanya terdapat 4 orang yang masih mengalami kecemasan. Sehingga dapat disimpulkan terapi meditasi dan yoga efektif untuk diterapkan dalam menurunkan gangguan kecemasan paska bencana banjir pada kelompok ibu rumah tangga di Desa Alat Kecamatan Hantakan, Hulu Sungai Tengah, Kalimantan Selatan.
\end{abstract}

Kata Kunci: Gangguan Kecemasan, Terapi Meditasi, Terapi Yoga

\section{A. PENDAHULUAN}

Bencana adalah peristiwa yang menyebabkan terjadinya kerusakan pada fungsi masyarakat seperti terganggunya perekonomian, hilangnya nyawa manusia, kerusakan sarana dan prasarana serta segala sesuatu yang dapat mengganggu kehidupan masyarakat jika tidak segera ditangani.
Indonesia merupakan salah satu negara yang memiliki banyak wilayah rawan bencana, baik bencana alam maupun non alam yang sering berdampak terhadap pengalaman yang traumatis (Nurcahyani, Dewi, Rondhianto, 2016).

Menurut Kementrian Kesehatan Tahun 2012, kejadian bencana alam di Indonesia terjadi sebanyak 211 kali 
dengan $\quad 53,3 \%$ bencana

hidrometeorologi yaitu $34,1 \%$ diantaranya adalah bencana banjir. Berdasarkan data Indeks Risiko Bencana Indonesia Tahun 2018, Kalimantan Selatan memiliki skor 145.21 yaitu berada pada kelas risiko tinggi wilayah yang rawan terjadinya bencana. Dari 397 kota/ kabupaten di Indonesia, Kabupaten Hulu Sungai Tengah Provinsi Kalimantan Selatan berada di peringkat 114 dengan skor 36.0 yaitu memiliki risiko tinggi terjadinya banjir (Nugroho dkk, 2018).

Kejadian banjir di Provinsi Kalimantan Selatan mengakibatkan 10 kota/ kabupaten terdampak banjir yang terjadi pada bulan Januari 2021 antara lain Kabupaten Tapin, Kabupaten Banjar, Kota Banjarbaru, Kota Tanah Laut, Kota Banjarmasin, Kabupaten Hulu Sungai Tengah, Kabupaten Balangan, Kabupaten Tabalong, Kabupaten Hulu Sungai Selatan dan Kabupaten Batola. Daerah terparah yang dilanda banjir adalah di Kabupaten Hulu Sungai Tengah yang mengakibatkan 11.200 jiwa mengungsi dan 64.400 jiwa terdampak, serta 3 orang meninggal (BNPB, 2021).

Kecemasan merupakan respon alami dari individu yaitu berupa takut yang tidak jelas disertai dengan perasaan ketidakamanan, ketidakpastian, isolasi dan ketidakberdayaan terhadap stress akibat bencana yang mengancam jiwa dan pengalaman yang traumatis dan berlangsung terus- menerus sehingga mengganggu kehidupan sehari- hari, baik kehidupan sosial dan bisa menjadi hal yang patologis yang nantinya dapat mengarah ke depresi dan gangguan jiwa jika tidak segera ditangani. Oleh karena itu, perlu sekali adanya penanganan yang tepat untuk korban bencana yang mengalami kecemasan (Stuart GW, 2013; Utami, Astuti, PH, 2017).

Upaya dalam mengurangi tingkat kecemasan pasca bencana dapat dilakukan dengan terapi komplementer berupa terapi meditasi dan yoga. Ada banyak bentuk meditasi yang mengajarkan cara mengamati pikiran, perasaan dan sensasi tanpa menghakimi. Meditasi dapat mengarahkan perhatian ke masa kini dengan rasa keterbukaan, ingin tahu dan penerimaan. Adanya meditasi dan yoga bisa menjadi kegiatan yang positif untuk mengurangi gangguan cemas dan stress yang dialami oleh masyarakat yang terdampak banjir. Meditasi juga dapat mengontrol ingatan yang mengganggu seperti pengalaman yang traumatis, sehingga korban bencana banjir dapat mengalihkan perhatian akan ingatan traumatis 
menjadi strategi koping dan pemecahan masalah yang efektif (Lang et al, 2012; Gallegos dkk, 2016).

Yoga juga merupakan salah satu terapi komplementer yang dapat diberikan kepada korban bencana. Yoga biasanya menggabungkan beberapa gerakan/ postur fisik, teknik pernapasan, relaksasi dan meditasi. Oleh sebab itu, yoga merupakan pendekatan holistik yang dianggap dapat mempersatukan tubuh, pikiran dan jiwa sehingga dapat memelihara kesehatan fisik dan mental (Cramer dkk, 2018). Yoga telah terbukti dapat mengurangi gejala PTSD dan diyakini dapat meningkatkan regulasi somatik dan kesadaran tubuh yang berperan penting dalam pengaturan emosi (Van der, 2014; Gallegos dkk, 2016).

Berdasarkan hasil wawancara oleh tim pengabdi kepada 7 warga di Desa Alat Kecamatan Hantakan Kabupaten Hulu Sungai Tengah, didapatkan bahwa 7 warga tersebut mengaku mengalami kecemasan seperti khawatir apabila terjadinya banjir susulan, sulit tidur dimalam hari, dan merasa takut jika hari hujan. Namun sampai saat ini belum pernah ada terapi yang diadakan oleh pemerintah atau lembaga setempat untuk mengatasi ataupun mengurangi rasa cemas yang dirasakan oleh warga.
Berdasarkan uraian tersebut, Tim Pengabdi Tertarik untuk menerapkan pengabdian kepada masyarakat melalui terapi meditasi dan yoga dalam menurunkan tingkat depresi, kecemasan dan stres pasca bencana banjir pada warga Desa Alat Kecamatan Hantakan.

\section{B. METODE}

Metode pengabdian kepada masyarakat ini adalah dengan pendekatan community development. Tim pengabdi bekerjasama dengan anggota masyarakat untuk melaksanakan program pengabdian. Pengabdian yang dilakukan melalui 3 tahapan yaitu tahap persiapan, tahap pelaksanaan dan tahan evaluasi.

Tahap persiapan dimulai dengan kerjasama antara tim pengabdi dengan kelompok masyarakat didaerah tersebut. Hasil diskusi didapatkan kelompok sasaran PKM ini adalah ibu rumah tangga yang berjumlah 20 orang dari RT yang berbeda-beda akan tetapi masih dalam satu desa yaitu Desa Alat Kecamatan Hantakan yang merupakan korban bencana banjir. Tim pengabdi kemudian mempersiapkan segala sarana dan prasarana yang dibutuhkan. Selanjutnya tim pengabdi merencanakan pelaksanaan kegiatan dan waktu pelaksanaanya. 
Pelaksanaan kegiatan dilakukan pada bulan Maret 2021 di Desa Alat, Kabupaten Hulu Sungai Tengah Provinsi Kalimantan Selatan. Sebelum dilakukan terapi meditasi dan yoga kelompok sasaran dilakukan pre test terlebih dahulu untuk melihat tingkat kecemasan dengan menggunakan kuesioner SRQ-20. Pengukuran tingkat kecemasan dilakukan sebelum dan sesudah kegiatan meditasi dan yoga hal tersebut dilakukan untuk menentukan tingkat kecemasan kelompok sasaran. Kuesioner SRQ-20 terdiri dari 20 pertanyaan, jika kelompok sasaran menjawab "Ya" lebih dari 6 pertanyaan maka kelompok sasaran tersebut megelami kecemasan. Setelah dilakukan pengukuran kemudian kelompok sasaran diberikan intervensi berupa terapi meditasi dan yoga secara terbimbing oleh tim pengabdi. Meditasi dilakukan 15 menit dengan diiringi music relaksasi dan dilanjutkan dengan 10 gerakan yoga dasar setiap satu gerakan dilaukan selama 30 detik.

Tahap evaluasi dilaksanakan setelah dilakukan terapi meditasi dan yoga. Tahap evaluasi ini dilakukan dengan menggunakan kuesioner SRQ20 kembali oleh tim pengabdi. Tujuan evaluasi ini adalah untuk mengukur tingat kecemasan kelompok sasaran dan untuk mengetahui pengaruh terapi meditasi dan yoga terhadap penurunan tingkat kecemasan pada masyarakat desa alat kecamatan hantakan yang merupakan korban bajir.

\section{HASIL DAN PEMBAHASAN}

Hasil kegiatan pegabdian masyarakat dengan menerapkan meditasi dan yoga pada kelompok sasaran pengabdian menunjukan bahwa lebih dari setengah responden berumur 30 - 39 tahun sejumlah 12 orang $(60,0$ \%). Usia merupakan kunci pemahaman terhadap bencana (Thoyibah dkk, 2019). Hal ini sejalan dengan penelitian yang dilakukan oleh Feist dalam Mamesah, Opod \& David (2018) tentang psikologi bahwa semakin bertambahnya usia, maka semakin matang pula kondisi psikologi seseorang, sehingga semakin baik pula individu tersebut dalam beradaptasi terhadap depresi, kecemasan dan stres yang dialaminya. Kecemasan juga lebih sering dialami oleh usia muda karena kurangnya pengetahuan dan pengalaman dalam melakukan adaptasi terhadap tekanan- tekanan psikologis yang ada, pengetahuan dan pengalaman yang banyak tentu membuat seseorang akan lebih siap dalam mengahadapi sesuatu yang terjadi dalam hidupnya (Buana \& Hijrianti, 2019). Penelitian 
yang dilakukan oleh Hidayat, Priambodo \& Nurhakim (2020) juga mendapatkan hasil bahwa orang muda lebih mudah mendapatkan tekanan psikologis dibandingkan orang tua, biasanya pada orang muda hal yang paling dikhawatirkan adalah masa depannya, terlebih lagi pada usia 30 - 39 merupakan masa usia dewasa akhir yang mana pada usia ini adalah masamasanya memikirkan keluarga, hal tersebut tentu menambah beban oleh individu tersebut karena disisi lain memikirkan dirinya sendiri dia juga memikirkan masa depan keluarganya.

Pengabdian kepada masyarakat menunjukan bahwa seluruh responden berjenis kelamin perempuan sejumlah 20 orang $(100 \%)$. Menurut penelitian hal ini dikarenakan pada wanita yang mengalami kecemasan yaitu disebabkan karena wanita mempunyai peranan penting dalam hal keluarga yaitu sebagai ibu rumah tangga yang melayani semua keperluan anak dan suaminya sehingga pada umumnya perempuan memiliki tingkat stres yang lebih tinggi. Dalam pengabdian ini didapatkan bahwa semua responden adalah berjenis kelamin perempuan, hal ini dapat disebabkan karena perempuan umumnya memiliki ambang stres yang lebih tinggi (Utami dkk, 2019). Secara alamiah, kecemasan lebih sering ditemukan pada perempuan merupakan dampak dari perubahan biologis terutama hormonal. Penelitian lain juga mengatakan bahwa perempuan lebih banyak memikirkan tentang bencana dan memilki keterikatan emosi yang dalam terhadap keluarganya dibandingkan laki-laki (Dwidiyanti dkk, 2018).

Menurut Stuart \& Sundeen (2017), selain jenis kelamin terdapat beberapa faktor juga yang dapat mempengaruhi kecemasan yaitu faktor usia, kedua pendidikan, ketiga sistem pendukung baik itu keluarga, lingkungan dan masyarakat sekitar yang memeberikan pengaruh pada individu dalam melakukkan sesuatu, sehingga hal tersebut dapat mempengaruhi mekanisme koping individu yang pada akhirnya mampu memberikan respon yang berbeda-beda disetiap peristiwa yang terjadi (Utami dkk, 2019).

Hasil pengabdian kepada masyarakat menunjukkan bahwa sebagian besar dari responden bekerja sebagai ibu rumah tangga sejumlah 11 orang $(55,0 \%)$. Menurut penelitian sebelumnya, ibu rumah tangga merupakan beban dalam seorang ibu untuk melakukan pekerjaan rutinitas yang ada di rumah, selain menjadi ibu rumah tangga, ibu juga berperan dalam 
menggantikan suami untuk membantu pengaturan ekonomi rumah tangganya. Hal tersebut dapat mengakibatkan banyaknya peran ibu rumah tangga menimbulkan pemicu tingkat kecemasan (Dwidiyanti dkk, 2018). Banyaknya peranan yang harus dilakukan oleh seorang ibu rumah tangga, sehingga menjadi stresor dari berbagai aspek dalam perannya tersebut. Taylor, Bogdan \& Devault (2016) dalam bukunya mengatakan bahwa individu yang melakukan terlalu banyak tugas dalam hidupnya terbukti memiliki tingkat stres yang lebih tinggi. Repetti dalam (Blecham, Lowell \& Garret, 2016) mengatakan bahwa kesehatan fisik dan mental pada wanita secara langsung dipengaruhi oleh kebutuhan mereka dalam melakukan koping terhdapat peran yang multiple sebagai seorang ibu rumah tangga, pekerja dan orang tua dari anak-anaknya. Hal tersebut dalam sebuah keluarga sehingga dapat menekan timbulnya faktor stres dan kecemasan.

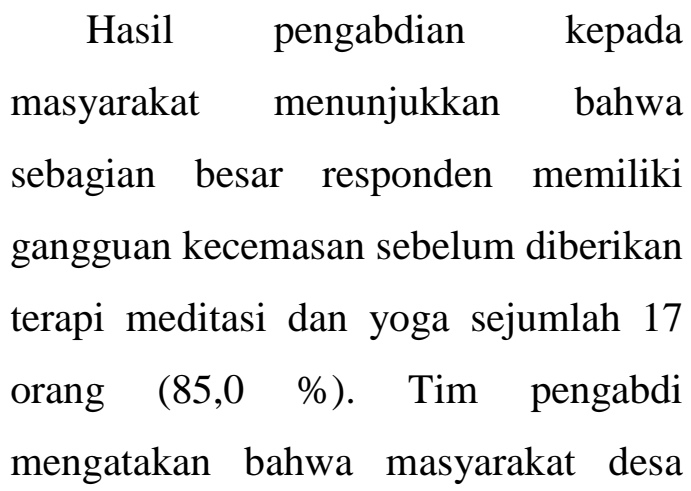

Alat kecamatan hantakan ini mengalami trauma pasca bencana banjir, hal tersebut ditandai dengan masyarakat merasa ketakutan ketika terjadi hujan dimalam hari apalagi hujan tersebut terjadi dimalam kamis karena masyarakat mengatakan beberapa bencana besar terjadi yaitu dimalam kamis, bahkan beberapa warga juga mengatakan beberapa warga cemas dan takut bencana tersebut terjadi kembali, dari kecemasan tersebut masyarakat sering tidak tidur jika terjadi hujan dimalam hanya untuk berjaga-jaga karena takut bencana tersebut terulang kembali.

Hatta (2016) menyebutkan bahwa pada saat kejadian traumatis dialami seseorang, individu tersebut akan merespon dan mengatasinya dengan mekanisme rekoveri yang dimilikinya sehingga tidak berdampak negatif pada kemudian hari, namun pada orangorang tertentu tidak terselesaikan dengan tuntas yang akan membekaskan luka dan sakit, dalam jangka waktu yang cukup lama yang kemudian berpengaruh terhadap perilakunya, orang-orang tersebutlah yang dikatakan mengalami stres pasca traumatic, dalam keadaan yang demikian seseorang memiliki risiko tinggi mengalami gangguan kesehatan mental seperti fobia, panik, 
depresi, kecemasan, stres dan obsesifkompulsif (Suwarningsih, Muhafilah \& Herawati, 2019).

Marsha, Diponegoro \& Utomo (2020) menyebutkan bahwa trauma bisa saja melanda siapa saja yang mengalami suatu peristiwa yang luar biasa seperti kematian orang yang dicintai, peperangan dan bencana alam seperti banjir, gempa bumi dan tsunami. Gangguan pasca trauma bisa dialami segera setelah peristiwa tersebut terjadi, bisa juga dialami secara tertunda sampai beberapa tahun sesudahnya. Korban biasanya mengeluh tegang, insomnia, kecemasan, sulit berkonsentrasi, depresi dan stres (Makahaghi \& Surudani, 2021).

Suwarningsih, Muhafilah \& Herawati (2019) menyatakan bahwa gangguan kecemasan pascatrauma biasanya akan nampak setelah sebulan atau setahun setelah bencana dengan ciri selalu merasa diburu oleh ketakutan yang berhubungan dengan bencana yang dialaminya seperti ketakutan akan berpisah dari orangtua atau keluarganya untuk selama-lamanya dan sering mengalami gangguan dalam tidur dengan mimpi-mimpi buruk, menjerit, dan mengompol di tempat tidur. (Makahaghi \& Surudani, 2021). Akumulasi trauma psikososial itu bisa berupa reaksi fisik maupun gejala-gejala psikis seperti rasa mual, murung, pendiam, mimpi buruk, kecemasan, merasa terancam, serta hilangnya harapan hidup. Bencana banjir mengakibatkan dampak yang dapat merugikan dikehidupan masyarakat yang dapat berupa tidak hanya kerugian fisik namun juga kerugian psikologis yaitu terganggunya kondisi mental karena kehilangan harta benda dan keluarga akibat bencana (Nurjannah dkk, 2012), sehingga memerlukan perhatian khusus berupa upaya atau kegiatan antisipatif supaya tidak menimbulkan dampak bagi kehidupan masyarakat selanjutnya (Makahaghi \& Surudani, 2021).

$\begin{array}{ccc}\text { Hasil pengabdian } & \text { kepada } \\ \text { masyarakat menunjukan } & \text { bahwa }\end{array}$
sebagian besar responden memilki gangguan kecemasan sebelum diberikan terapi meditasi dan yoga sejumlah 17 orang $(85,0 \%)$ kemudian setelah mengikuti terapi meditasi dan yoga yang mengalami gangguan kecemasan hanya ada 4 orang $(20,0 \%)$. 
Tabel 1.1 Hasil Pengukuran Kecemasan Sebelum dan Sesudah diberikan terapi Meditasi dan Yoga

\begin{tabular}{|c|c|c|c|c|}
\hline \multirow{2}{*}{$\begin{array}{c}\text { No } \\
\text { Responden }\end{array}$} & \multicolumn{4}{|c|}{ Skor Kuesioner } \\
\hline & $\begin{array}{l}\text { Pre } \\
\text { Test }\end{array}$ & Kategori & $\begin{array}{l}\text { Post } \\
\text { Test }\end{array}$ & Kategori \\
\hline 1 & 13 & Cemas & 3 & Normal \\
\hline 2 & 18 & Cemas & 5 & Normal \\
\hline 3 & 11 & Cemas & 7 & Cemas \\
\hline 4 & 16 & Cemas & 5 & Normal \\
\hline 5 & 7 & Cemas & 4 & Normal \\
\hline 6 & 13 & Cemas & 6 & Cemas \\
\hline 7 & 11 & Cemas & 5 & Normal \\
\hline 8 & 9 & Cemas & 4 & Normal \\
\hline 9 & 15 & Cemas & 2 & Normal \\
\hline 10 & 3 & Normal & 0 & Normal \\
\hline 11 & 8 & Cemas & 4 & Normal \\
\hline 12 & 11 & Cemas & 7 & Cemas \\
\hline 13 & 5 & Normal & 0 & Normal \\
\hline 14 & 10 & Cemas & 2 & Normal \\
\hline 15 & 5 & Normal & 1 & Normal \\
\hline 16 & 8 & Cemas & 4 & Normal \\
\hline 17 & 11 & Cemas & 5 & Normal \\
\hline 18 & 12 & Cemas & 4 & Normal \\
\hline 19 & 15 & Cemas & 6 & Cemas \\
\hline 20 & 7 & Cemas & 4 & Normal \\
\hline
\end{tabular}

Seseorang dapat memulihkan serta mempertahankan kesehatan fisik maupun emosional setelah terjadi traumatis atau stressor yang bermakna menggunakan faktor protektif yang ada yaitu faktor sosial budaya meliputi usia, jenis kelain, pendidikan, penghasilan, pekerjaan, latar belakang budaya, keyakinan religi dan pengalaman sosialisasi yang berdampak pada kemampuan seseorang dalam menghadapi bencana menurut stuart dalam Suwarningsih, Muhafilah \& Herawati (2019).

Menurut tim pengabdi gangguan kecemasan dapat ditangani oleh individu itu sendiri, lingkungan serta melalu kegiatan- kegiatan positif. Salah satu kegiatan tersebut adalah meditasi dan yoga. Menurut Sindhu dalam Lukmanulhakim \& Agustina (2018) menyebutkan bahwa salah satu jenis relaksasi yang dapat menurunkan kecemasan dan belum banyak dilakukan di Indonesia adalah meditasi dan yoga, melakukan nafas dalam merupakan salah satu pengelolaan kecemasan yang paling sederhana yang bisa dilakukan dimanapun dan kapanpun dan akan lebih efektif jika dilakukan secara teratur. Zuhrotunida (2020) menyebutkan bahwa meditasi \& yoga merupakan jenis olahraga tubuh, pikiran dan mental yang sangat membantu untuk menenangkan pikiran serta mengurangi kecemasan.

Meditasi dan yoga yang dilakukan mencakup berbagai relaksasi, mengatur postur serta mengatur pernafasan selama 30 menit serta dilakukan secara terbimbing (Zuhrotunida, 2020). Meditasi dan yoga dapat menstimulus dalam pengeluran hormon endorphin, hormon ini merupakan neuro peptide yang dihasilkan oleh tubuh pada saat tubuh rileks dan tenang. Salah satu 
fungsi dari hormon ini adalah sebagai obat penenang alami yang dihasilkan oleh tubuh khususnya diproduksi otak yang dapat menstimulus adanya rasa nyaman dan meningkatnya kadar endophrin dalam tubuh untuk mengurangi rasa cemas dan stres (Lukmanulhakim \& Agustina, 2018).

Hal tersebut juga dikuatkan oleh Syafi,i (2020) bahwa mengatur pernafasan serta melakukan gerakan yoga dapat mengaktifkan sistem syaraf parasimpatis terutama dengan merelaksasikan jaringan paru dan saraf vegal, hal tersebut menyebabkan respon fisiologis ditandai dengan penurunan denyut jantung, tekanan darah, tingkat metabolisme dan konsumsi oksigen sehingga tubuh merasa lebih rileks dan tenang. Tim pengabdi lain juga menyebutkan Penurunan kecemasan yang dipengaruhi oleh meditasi dan yoga ini akibat dari rasa ceria dan nyaman yang dirasakan oleh warga desa Alat selama mengikuti kegiatan meditasi dan yoga (Mujiono, Muhammad dan Chandra, 2020). Menurut Spielberger dalam Zuhrotunida (2020) secara teoritis kecemasan akan turun jika individu mengalami relaksasi pada tubuhnya.

Gambar 1. Kegiatan Pretest

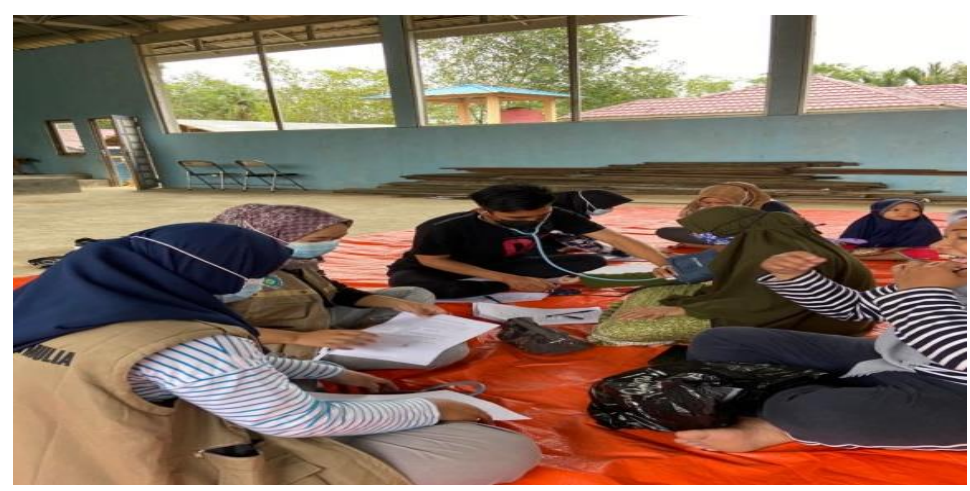

Gambar 2. Kegiatan Terapi Meditasi dan Yoga
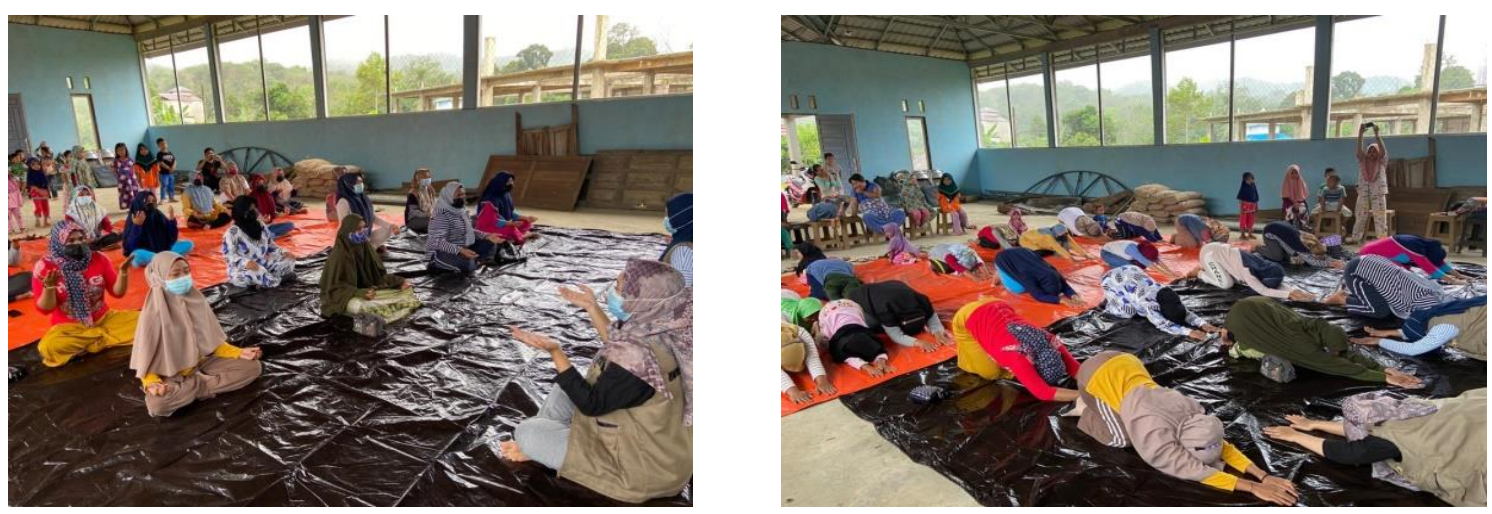
Gambar 3. Kegiatan Posttest

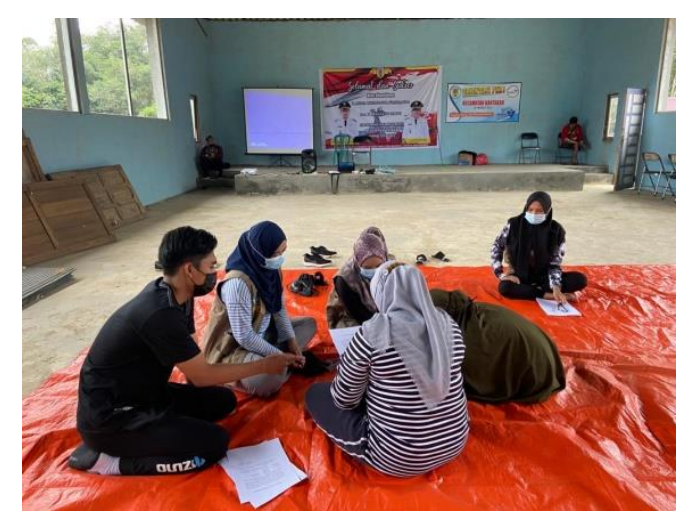

\section{Kesimpulan}

Upaya dalam mengurangi tingkat kecemasan pasca bencana dapat dilakukan dengan terapi komplementer berupa terapi meditasi dan yoga. Terapi meditasi dan yoga dinilai efektif dalam menurunkan ganguan kecemasan pada masyarakat korban bencana banjir.

Cramer, H., Anheyer, D., Saha, F. J., \& Dobos, G. 2018. Yoga for Post Traumatic Stress Disorder- A Systematic Review and MetaAnalysis. BMC Psychiatry. 18(1): 19.

https://bmcpsychiatry.biomedcentral. com/track/pdf/10.1186/s12888-0181650-X.pdf.

Badan Nasional Penanggulangan Bencana. 2021. 10 Kabupaten/ Kota Terdampak Banjir di Kalimantan Selatan. https://bnpb.go.id/berita/-update-10kabupaten-kotaterdampak-banjir-dikalimantan-selatan.

Blechman EA, Lowell ES, Garrett J. 2016. Prosocial Coping And Substance Use During Pregnancy. Addictive Behaviors, 24, 99-109.

Buana BC, Hijrianti UR. 2019. Hubungan Persepsi Masyarakat Terhadap Pemerintah Dengan Kecemasan Menghadapo Rencana Pembangunan Jalur Ganda Kereta Api. Proyeksi. 14(2):

94-114.

http://jurnal.unissula.ac.id/index.php/ proyeksi/article/download/5006/433 7 . 
Hatta K. 2016. Trauma dan Pemulihannya. Aceh: Dakwah Ar- Raniry Press

Hidayat FS, Priambodo AP, Nurhakim F. 2020. Gambaran Kualitas Hidup Masyarakat Korban Banjir. Journal Of Nursing Care. 3(3): 181-190. http://jurnal.unpad.ac.id/jnc/article/d ownload/25680/13858.

Lukmanulhakim, Agustina D. 2018. Pengaruh Yoga Pernapasan (Pranayama) Terhadap Kecemasan Keluarga Pasien Kritis di Ruang ICU. Jurnal Aisyah. 3(1): 77-86.

https://aisyah.journalpress.id/index.p hp/jika/article/download/LukAgus/p $\underline{\mathrm{df}}$

Makahaghi YB, Surudani CJ. 2021. Pengalaman Keluarga Menghadapi Trauma Pasca Bencana Alam Di Kampung Lebo Kecamatan Manganitu. Jurnal Ilmiah Sesebanua. 5(1): 23-30.

http://ejournal.polnustar.ac.id/jis/arti cle/view/367/291.

Mamesah NFA, Opod H, David L. 2018. Gambaran Tingkat Kecemasan pada Warga yang Tinggal di Daerah Rawan Longsor di Kelurahan Ranomuut Kota Manado. Jurnal eBiomedik. 6(2): 141-144. https://ejournal.unsrat.ac.id/index.ph p/ebiomedik/article/download/22108 121809.

Marsha GC, Diponegoro AM, \& Utomo, UHN. 2020. Psychological WellBeing Masyarakat yang Terdampak Banjir: Studi Kasus di Kecamatan Bati-Bati. In Prosiding Seminar Nasional Magister Psikologi Universitas Ahmad Dahlan (Vol. 1, pp. 1-7).

Mujiono A, Sobirin MA, \& Ropyanto CB. 2020. Peran Yoga Dalam Menurunkan Kecemasan Pada Pasien
Jantung. The Shine Cahaya Dunia Ners, 5(1).

Muslaini R, Sofia N. 2020. Efektivitas Terapi Zikir Terhadap Post Traumatic Stress Disorder (PTSD) Pada Penyintas Tsunami Palu. Jurnal Psikologi Islam dan Budaya. 3(2): 123-134.

https://journal.uinsgd.ac.id/index.php /jpib/article/download/8749/4857.

Nugroho PC, Pinuji SE, Ichwana AN, Nugraha A, Wiguna S, Syauqi, Randongkir RE, Shabrina FZ, Septian RT, Iriansyah AA, Hafiz A, Hamzah A, Seniarwan, Setiawan A. 2018. Indeks Risiko Bencana Indonesia. Jakarta: Badan Nasional Penanggulangan Bencana.

Nurcahyani F, Dewi EI, Rondhianto. 2016. Pengaruh Terapi Suportif Kelompok Terhadap Kecemasan Pada klien Pasca Bencana Banjir Bandang di Perumahan Relokasi Desa Suci Kecamatan Panti Kabupaten Jember. E-Jurnal Pustaka Kesehatan. 4(2): 293-299.

https://jurnal.unej.ac.id/index.php/JP $\underline{\mathrm{K} / \text { article/view/3205. }}$

Suwarningsih, Muhafilah I, Herawati TM. 2019. Perubahan Kondisi Psikososial dan Spiritual Pada Korban PTSD (Post Traumatic Stress Disorder) Pasca Banjir Bandang di Kota Garut Jawa Barat. Jurnal Ilmiah Kesehatan. 11(1): $1-11$. http://journal.thamrin.ac.id/index.ph $\mathrm{p} / \mathrm{jikmht/article/download/62/61.}$

Stuart, GW, Sundeen, JS. 2017. Keperawatan Jiwa (Terjemahan), alih bahasa: Achir Yani edisi III. Jakarta: EGC.

Suwarningsih, Muhafilah I, Herawati TM. 2019. Perubahan Kondisi Psikososial dan Spiritual Pada Korban PTSD 
(Post Traumatic Stress Disorder) Pasca Banjir Bandang di Kota Garut Jawa Barat. Jurnal Ilmiah Kesehatan. 11(1): $1-11$. http://journal.thamrin.ac.id/index.ph $\mathrm{p} / \mathrm{jikmht} /$ article/download/62/61.

Syafi'i A. 2019. Pengaruh Terapi Masase, Masase Dengan Yoga, Dan Masase Dengan Meditasi Terhadap Penurunan Tekanan Darah Dan Tingkat Kecemasan Pada Penderita Hipertensi. Massage for Sport Therapy and Injury, 1(1)

Taylor, S. L., Bogdan, R., DeVault, M. L. 2016. Introduction to qualitative research methods: a guidebook and resource (4th ed). Hoboken, NJ: John Wiley

Thoyibah Z, Dwidiyanti M, Mulianingsih M, Nurmayani W, Wiguna RI. 2019.
Gambaran Dampak Kecemasan dan Gejala Psikologis pada Anak Korban Bencana Gempa Bumi di Lombok. Journal of Holistic Nursing and Health Science. 2(1): 31-38. https://ejournal2.undip.ac.id/index.p hp/hnhs/article/download/5328/2861

Utami, TW, Astuti YS, PH L. 2017. Hubungan Kecemasan dengan Depresi Pada Anak Sekolah Dasar. Jurnal Keperawatan. 9(1): 1-5. http://stikeskendal.ac.id/journal/inde x.php/Keperawatan/article/download 145/29.

Zuhrotunida, Z. (2020). Efektifitas Yoga Terhadap Tingkat Kecemasan Ibu Bersalin: Studi Literatur. Jurnal JKFT. $5(2): \quad 75-81$. http://jurnal.umt.ac.id/index.php/jkft. 